\title{
MAPPING THE AGRODIVERSITY IN BOGOTÁ - THE PLATFORM MAPEO AGROECOBOGOTÁ
}

\author{
K. PINILLA, B. HOINLE, A. MAHECHA-GROOT \& J. CEPEDA \\ Agustín Codazzi Geographical Institute (IGAC), University of Hamburg, Rutgers University, \\ National University of Colombia.
}

\begin{abstract}
Counter-mapping is a useful tool to counteract the hegemonic forms of creating maps and overcoming territorial logics of domination. The purpose of counter-mapping projects is mapping and visualizing information to be monitored in real time and generate collaborative creation processes for the creation of alternative learning networks and interactive community cartography that works as a territorial appropriation tool. In Colombia, the counter-mapping platform AgroEcoBogotá is inspired by the social, environmental and agroecological movements that create new ways of doing and being in this world through agroecological initiatives, allowing the emergence of transformative pathways of the agrifood system in the metropolitan area of Bogotá, the capital of the country. The platform is a tool to promote and give visibility to the movement of agroecology in Bogotá, through the mapping of huertas urbanas (urban farms and gardens) and other urban agriculture projects. The aim is to create solidarity links between different urban and peri-urban food initiatives of Bogotá and its neighborhoods and to connect the existing networks of urban agriculture with the rural sphere. The motivation to create the platform was the observation and acknowledgment of the lack of a network of networks that could encourage the interaction and strengthening of agroecological initiatives. With the example of one mapping-point, Casa Taller Las Moyas in the Eastern Hills of Bogotá (Cerros Orientales) we want to illustrate the importance of huertas urbanas as spaces of local community empowerment. In this context, counter-mapping also serves as a resource for resistance and grassroots appropriation of space. As a conclusion, we will reflect about the challenges that AgroEcoBogotá is facing in the effort to make visible the agroecological movement of Bogotá, as well as, to strengthen the existing networks in Bogotá and their rural food supply connections in different parts of the region of Cundinamarca.

Keywords: agroecology, counter-mapping, critical cartography, social movements, urban agriculture.
\end{abstract}

\section{INTRODUCTION}

Recently, the urban agriculture movement in Bogotá, the capital of Colombia, is growing and is attracting public attention. During the last decades, the metropolitan region of Bogotá was growing at an accelerated tempo due to the arriving of a considerable number of migrants from different rural areas, many of them displaced by the dynamics of the armed conflict. Therefore, the huertas urbanas, hereafter referred to as urban gardens, have become spaces which firstly offer means for subsistence but in the long run can contribute to community empowerment, especially in the lower class neighborhoods. The huertas are fruit and vegetable gardens, but in the context of Colombia la huerta is also a privileged space in the life of rural communities. Generally, it is located next to the houses, and farmers weave a vital relationship with the earth and territory, through the diversity of plants and microorganisms in the ground. In an urban context, las huertas urbanas are also spaces for growing food, as well as, spaces for other non-productive functions such as education, food sovereignty, social cohesion. Despite the enormous potential of urban agriculture to integrate rural migrants in urban contexts such as Bogotá, efforts are still required to be recognized as a possibility for inhabiting the city in a more decent way.

In this context, the initiative AgroEcoBogotá (https://agroecobogota.crowdmap.com/) was launched as a platform (Fig. 1) [1] to give greater visibility to the existing urban farming 
projects. Its aim is to deepen and strengthen the links between the various agroecological projects in the different parts of the city and to promote the local agroecological movement. The participation within the platform allows open access to the local urban farmers who can directly join the mapping process. Through its interactive configuration the platform gives the possibility to georeference information in real-time from every place of the world. This allows to generate processes of collaborative cartographic creation, both digital or analogue. Therefore, the initiative opens up the way for the exchange of knowledge about the reproduction of native seeds, medicinal plants and preparation of local recipes. Moreover, it aims to promote the food networks with the regional agroecological projects in the department of Cundinamarca (Colombia is divided into 32 departamentos (Departments), which are in turn subdivided into municipios (municipalities) and cities). By doing so, the initiative AgroEcoBogotá tries to challenge the hegemonic forms of knowledge production. This means forms of knowledge production that were perpetuated by dominant sectors of the society where the economic power (e.g. agribusiness) is situated. Instead of reproducing dominant representations of the urban landscape the methodology of counter-mapping opens up spaces for the visions, perspectives, and experiences of the local inhabitants. So, the intention is to give greater public visibility to groups who have been affected by territorial conflicts which often are not visible in the conventional maps. This kind of collective mappings could be called 'a process of creation which subverts the place of enunciation to challenge the dominant narratives about territories' [2]. Actually, the mapping process is constituted by 80 references of urban and periurban agroecological projects in Bogotá and its surroundings (Fig. 1). Nevertheless, in the metropolitan area of Bogotá there are still much more agroecological initiatives to map and grassroots processes to visualize.

\section{¡Iniciativa para compartir experiencias de agricultura en Bogotá y sus alrededores!}

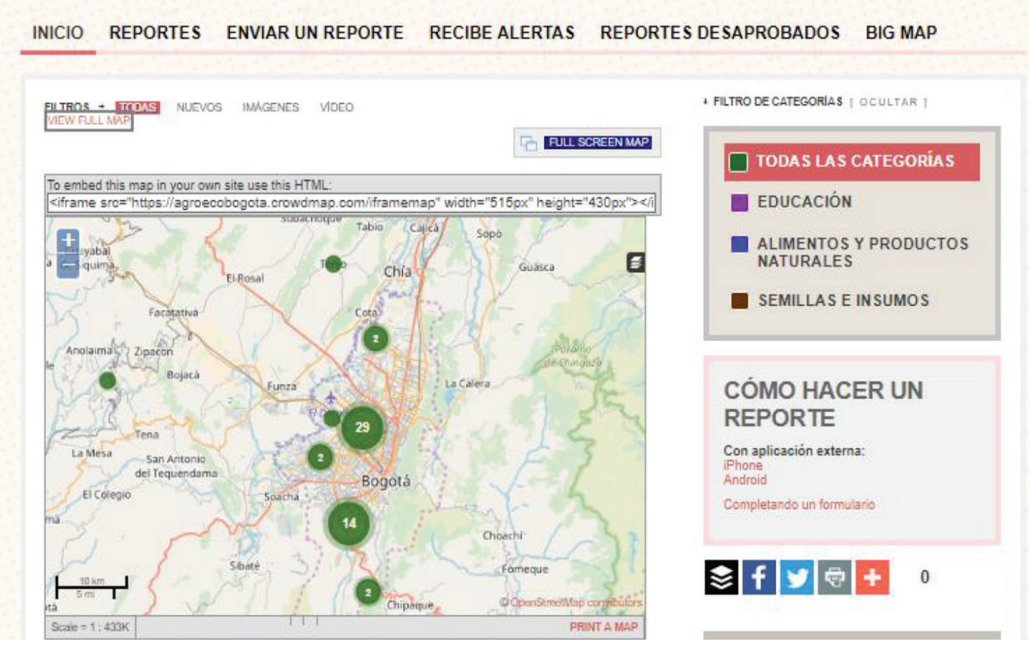

Figure 1: Homepage from AgroEcoBogota platform. Source: Taken from agroecobogota.crowdmap.com [1]. 
This paper has five sections. In the first section, we give an overview of the relation of social mapping and real-time mapping, and its importance of empowering citizen participation for the identification of socio-spatial change and transformative actions in space. Following that, we reflect on the relevance of applying collective mapping processes in the context of urban agriculture. In the third section, we analyze how the proposal of counter-mapping was put into practice in the creation of the platform AgroEcoBogotá by mapping the initiatives of urban agroecology in the metropolitan region of Bogotá. In the fourth section by highlighting one mapping point - the agroecological project Casa Taller Las Moyas - in the Eastern Hills of Bogotá (Cerros Orientales) we want to explore the potential of the mapping tool for processes of appropriation of space. Casa Taller Las Moyas is located in a context of ecological degradation and social marginalization in the informal neighborhood San Luis, so it constitutes a place of territorial conflicts on one hand and local communitarian processes of resistance on the other hand which makes this example especially interesting in the context of counter-mapping. Finally, in the fifth section, we will discuss the opportunities and challenges that the platform offers as a virtual space for promoting the visibility of the agroecological networks in the metropolitan area of Bogotá. As the mapping process of AgroEcoBogotá (Fig. 1) [1] is still in process (as most social processes are), we do not finish the article with final results, instead we conclude with an outlook about the perspectives, potentials and challenges for the future.

\section{FROM SOCIAL MAPPING TO REAL-TIME MAPPING}

Within the dominant cartographic representations, an entity is responsible for writing and marking the territory in a unified way, denying the possibility of seeing the different ways of perceiving and interacting in space. Instead, social cartography tries to make visible and legitimize the struggle for the search for alternative representation spaces of the different social actors involved in a specific territorial dynamics [3], [4]. Citizen participation online is an instrument that promotes the generation of collective knowledge and interactively allows to identify alternatives that help understand and act against urgent territorial issues. Social mapping has become an enhancing device for citizen participation for the identification of socio-spatial change and transformation actions. In this regard, Herrera [5] states

"[social-mapping] emerges as a new tool for planning and social transformation. It is currently being used as support in community organization processes through decentralized and democratic participatory planning in which the participation of all local actors acquires great importance. Besides, the social cartography of a territory is proposed as a new instrument for the construction of knowledge from participation and social commitment, enabling the transformation of it." [5]

The emancipatory ideals of social-mapping, together with the potential of free software, have created counter-mapping tools such as crowdmapping. Ushahidi, the technological corporation, is an excellent example of an open-access and open-source real-time mapping portal, that have the possibility of personalizing themselves through the collective knowledge of citizenship. Due to the difficulty in obtaining accurate information about the detail of the civil rights violations that were co-occurring in some African cities, Ushahidi arose as an alternative for mapping to more real story told by the citizenship. In short, the contribution of the same citizens was the most legitimate knowledge of the reality that they were living. Citizen participation was the most valuable element of denunciation and social control that legitimized the birth of geographic information system to systematize collective knowledge generated in real time [6]. 
We emphasize that for the creation of these platforms there are two different methods, which go according to the public that needs them. For the developers, the free open source database (ODbL) was made available where a programming language is used (either for Windows or Linux) with the possibility of collective improvement, and, while retaining the copyright of the generators of the information, that is, facilitating the creation of collective knowledge on the web and free licensing. For people who do not master programming words, the extension releases the standard code base that allows the automatic creation of platforms, accompanied by a broad level of web customization [6].

While there is a consumer relationship regarding access to technologies and the Internet in most Latin American countries, this does not mean that valuable and innovative knowledge cannot be generated to understand territorial dynamics. What it needs is to make the territorial actors visible and create interaction spaces of their knowledge intending on creating a shared and emancipatory knowledge.

\section{WHY MAPPING URBAN AGRICULTURE?}

Generally, since the formation of large cities due to industrialization, urban agriculture has been developed in cities to alleviate food shortage and improve the quality of life. With great boom periods related to crisis, such as the world wars, and now, environmental and social problems that have led to think of urban agriculture as an alternative for countries in both the North and the Global South. Particularly in the Global South, urban agriculture has been studied from its role in the construction of livelihood strategies for people who do not have access to social safety nets [7-9].

Urban agriculture in Bogotá response to the global trend we mentioned above, related with urban expansion and local migrations during the first half of twenty century. This local migrations were mostly from the countryside, principally from the departments of Boyacá, Cundinamarca, Santander and Tolima [10]. Thus, we can imagine that these peasants bought not only cultivation habits and their own knowledge, but also native seeds and recipes, which were resignified in the urban space. The orchards in Bogotá are therefore spaces for exchange of knowledge and urban-rural practices.

The institutionalization of urban agriculture in Bogotá takes place in 2004, during the mayor's office of Luis Eduardo Garzón (2004-2007) in the framework of food security policy. Currently, in Bogotá there is public policy on urban agriculture or 'Agreement 605 of 2015 of the Council of Bogotá', however, this strategy has been limited implementation due to lack of budget. One of the proposals of this policy is the SIGAUPA or geographic information system of urban and peri-urban agriculture, tool that is under construction due precisely to budget constraints.

In a global regarding of urban agriculture, it can be considered that its practice has been continuous, but in many cases it is found that the state supports in contrast have been intermittent, so the presence of civil society around the urban farming is vital to their survival and it remains important today throughout the world [11]. This is also applicable to the decision making tools for the development of this activity, thus, the proposal of AgroEcoBogotá responds to the need to generate this type of self-managed and independent strategies.

Based on the big picture, we consider that the mapping of urban agriculture will allow us to understand:

1. The scale of where and what services are available in the city to make possible its monitoring, the close follow-up of the implementation of public policies on urban agriculture, 
the management of community-applied supplies, that is, this vision proposes to mapping as tool for decision making.

2. The map as a tool for the communication of untold and alternative stories of doing agriculture, as well as for the transmission of important information within the construction of territoriality.

3. Support for assessing the sustainability of the city and its degree of food sovereignty from the base communities.

4. Visibility and empowerment of people and groups dedicated to urban agriculture.

5. Support for better management of local networks and the district network of urban farmers.

6. Show the current and potential importance of urban agriculture for local and regional development.

\section{THE PROCESS OF THE PLATFORM MAPEO AGROECOBOGOTÁ}

The purpose to found the platform AgroEcoBogotá was to create networks between the different urban and periurban gardens of Bogotá. The idea came up because of three observations: (a) In many cases the urban farmers of the same neighborhood don't know each other; (b) More and more inhabitants of the urban neighborhoods would like to buy fresh organic vegetables but they do not know where; (c) In Bogotá, there are existing several networks at the level of the local neighborhoods and districts. But at that time there wasn't any network at the metropolitan scale that connects all the local networks.

These observations were made by people engaged in fieldwork in the peri-urban and urban gardens of Bogotá. They gathered for an exchange about ideas about their universitary theses and social activism. In these meetings the idea came up to visualize all the urban farming projects they came to know during their field visits. With the idea to strengthen the urban farming movement of Bogotá they started to organize the platform since 2014. The first announcement was made by the 'I Encuentro de Agricultura y Educación para la permanencia de la vida - Permaculturas Colombia' (First Meeting of Agriculture and Education for the Sustainability of Live - Permacultures in Colombia) organized by the Department of Geography at the National University of Colombia. The first rapprochement of mutual learning with the technology of the platform was pursued with the network for alternative education REEVO (Red de Educación Alternativa). This organization already had undertaken a mapping process with initiatives of all over the world.

Another important precedent was a audiovisual project about urban agriculture in Bogotá for the online journal Razón Pública initiated by a group of scholars and activists. The collective was visiting several urban gardens in the central and peripheral lower class neighborhoods like La Perseverancia, Diana Turbay (local district Rafael Uribe Uribe) and in the rural side of Usme (still part of Bogotá). During the shooting of the videos and the interviews with the local urban farming activists we recognized the huge diversity of the urban agriculture landscape of Bogotá: Every urban garden has its own characteristics. Some work more with native seeds, others with medicinal plants and some are engaged in the elaboration of traditional recipes.

The urban garden in the local neighborhood of Diana Turbay was an impressive example of how the different urban gardens are interconnected with each other at local scale. There are different forms of exchange that the urban gardeners are practising like exchange of recipes, seeds, plantlets and knowledges. Moreover, every month, they meet to help each other in the gardens, a practise called 'minga' in the Andean Regions. So, by their daily practices, they are 
already experimenting economic alternatives and creating Commons in a material and symbolic way: the material foundations to build up a garden (soil, seeds) and symbolic (agroecological knowhow). By doing so, they are creating links of solidarity and neighborship within their district. In cases like this, the platform could help to facilitate the communication and communitarian organization between the urban gardens. One example for the creation of networks at the district scale is the Network of Communitarian Gardens in Ciudad Bolívar (Red de Huertas Comunitarias in Ciudad Bolívar). They are also organizing 'mingas' and coordinating agroecological markets with the vegetables from the gardens in the lower class neighborhoods of Ciudad Bolivar. Nevertheless, in most of the neighborhoods, the urban garden initiatives are rather disconnected and the people with the same agroecological ideas don't know each other. For this reason we came up with the idea of the platform Mapeo AgroEcoBogotá to give the urban gardening projects more visibility and to create more networks on a wider scale between the already existing urban gardening networks. We were inspired by some international mapping processes like the mapping of the communitarian and intercultural gardens of Berlin undertaken by the Kollektiv Orangotango. In this mapping process they referenced 99 urban gardening projects [12].

With this proposal in mind we met at the Encounters of Permaculture held up near by the National University of Bogotá. In this time the collective of AgroEcoBogotá was founded, originally by four persons motivated by the interest to visualize the diversity of the urban agriculture of Bogotá in a cartographic way. The collective was formed by people of different areas and countries but all of them engaged in the issues of agroecology and participatory action research. Since 2015 we were meeting constantly to define the basic configurations of the platform. After several discussions we defined three categories to differentiate the distinct focal points of the urban gardens: seeds, alimentation and education. This differentiation is useful to promote the different objectives that the gardens are pursuing in the reproduction of native seeds and in spreading their experiences by workshops. We installed the platform in an open source format based on Open Street Map to guarantee the open access and interactive configuration of AgroEcoBogotá.

\section{EXAMPLE OF ONE MAPPING POINT - CASA TALLER LAS MOYAS IN SAN LUIS, CHAPINERO, BOGOTÁ}

In the eastern hills of Bogotá, in the informal neighborhood called San Luis, where urbanity meets rurality and the dark green forests of the mountains, there is the location of Casa Taller Las Moyas. This is a self-managed community project for the care of children in the absence of the state, and the urban agroecological initiative is part of the strategies of this vital project. This urban agroecological project is situated within an informal neighborhood called San Luis. In the streets of San Luis you find peasants with the traditional ruanas (typical Colombian poncho) and youth people listening to urban reggaeton music. San Luis is a self-built neighborhood, with the will and ingenuity of the villagers themselves; it was a transit point due to the transportation of coal and wood from Bogotá to La Calera. This place belongs to the borough of Chapinero and is populated by migrants from the countryside to the city or from the city to the surroundings due to the multiple forms of political and economic violence in Colombia. The people had to build up their own infrastructure, so until today the neighborhood has its own community-based aqueduct. The inhabitants were fighting for their formal recognition by the administration of Bogotá, but until now only one part of the neighborhood was legalized. Recently, San Luis is experiencing rapid transformation. As one part continues as an informal, marginalized neighborhood, in the other part real estate firms are investing in upper class housing projects. This creates more and more social inequality within the 
neighborhood. In this conflictive context, the urban agroecological project Casa Taller Las Moyas tries to build up an alternative of communitarian organization and integration of different generations.

Casa Taller is like an open meeting point in San Luis. Children come here to do their homework, especially when their parents are all day long at work and they would be alone at their house. Some young people meet to make music, soaps, creams, ointments, grow plants, and all the activities that the same relationships of life make them learn. They are considered an active community school and with the task of rethinking as worthy human beings on a constant basis. On weekends they plan activities such as the mingas and people from different parts of Bogotá join the work in the urban garden and learn more about plants and ancestral recipes. Mingas are an Andean tradition of collaborative work that was practiced since generations by the indigenous communities. The aim is to organize work in a solidarity form based on mutual self-help. These ancestral practices find also a revival in the today's urban farming projects. To the mingas in Casa Taller Las Moyas usually come activists of the network 'Guardianes de Semillas' (Guardians of Seed). These women share their knowledge about seed reproduction and conservation in urban gardens. Therefore, the urban garden in Casa Taller Las Moyas is a place of exchange between different, experience-based ancestral knowledges (diálogo de Saberes). By doing so, the women of the seed movement contribute to maintain the hugh agrobiodiversity in seeds (maize, beans, potatoes, herbs) that is circulating between the urban farming projects in Bogotá. For Nicolasa, the founder of the project, Casa Taller is a free education initiative in which sowing is a pedagogical tool to reconnect with nature within the city. Casa Taller is a family of generations of the city of Bogotá that meet to learn and share in a collaborative and emancipatory way, they offer and demand communitarian learning for the production of different personal and useful things for life deodorants, creams, ointments, notebooks among others. For the children, the things that they elaborate are always a possibility for learning from a young age how they can generate their own money and dignify themselves from the pedagogy of love. This pedagogy allows to find the power that all human beings have to be and feel worthy thanks to the responsibilities they assume, instead of the begging discourse. At the time of creating the products, children and young people apply the knowledge related to the different branches of knowledge, thus applying project-based learning. They have received since the foundation of Casa Taller collaborative stimuli from the same inhabitants and the network of contacts that they have achieved thanks to their work and effort. Casa taller is part of the AgroEcoBogotá mapping for being a reference for agroecological movement concentration.

\section{CONCLUSION: CHALLENGES AND PERSPECTIVES}

The mapping platform AgroEcoBogotá has still some challenges to face. One of them is to create more opportunities for an encounter between the agroecological initiatives and the inhabitants of Bogotá where they could exchange more their work and knowledge. There are still some challenges to integrating more rural migrants and displaced people in the urban gardens as an alternative for communitarian organization in their local neighborhoods. Another challenge is to transcend the registrations already made from the sum of several individual points to a collective sense of being part of a pivotal social movement. The latter would also be useful to multiplicate collaborative ethics within the urban gardens based on the principles of agroecology and the commons.

The mapping platform has a enormous potential to strengthen the agroecological movement in Bogotá. The platform could be a tool to link more the rural agroecological producers and urban consumers and therefore create spaces for experiences with community supported 
agriculture with the idea to construct a juster and more sustainable food system between city and countryside.

Furthermore, the platform has also a significant potential for the documentation and research in peri-urban and urban agriculture. As the information gets continuously actualized, the platform is much more dynamic and close to the urban farming activists. However, the most significant aspect is that the urban farmers themselves are appropriating the platform and use it for their purposes. How can we promote the autonomy of the mapping process? Also, which tools would be helpful for this aim? These are some questions that guide the following processes with the platform in the future.

\section{REFERENCES}

[1] Agroecobogotá. Crowdmapping extension from Ushahidi Technology. Online. https:// agroecobogota.crowdmap.com (accessed on 23 May, 2018).

[2] Iconoclasistas (eds.). Manual del mapeo colectivo: recursos cartográficos críticos para procesos territoriales de creación colaborativa. Tinta Limón: Buenos Aires, 2013.

[3] Barrera Lobatón, S., Reflexiones sobre Sistemas de Información Geográfica Participativos (SIGP) y cartografía social. Cuadernos de Geografía-Revista Colombiana de Geografía, (18), pp. 9-23, 2009. https://doi.org/10.15446/rcdg.n18.12798

[4] Oslender, U., Ontología relacional y cartografía social:¿ hacia un contra-mapeo emancipador, o ilusión contra-hegemónica? Tabula Rasa, (26), pp. 247-262, 2017.

[5] Herrera, J. Cartografía social. Online. https://juanherrera.files.wordpress. com/2008/01/ cartografia-social.pdf (accessed on 23 May, 2018).

[6] Okolloh, O., Ushahidi, or 'testimony': Web 2.0 tools for crowdsourcing crisis information. Participatory Learning and Action, 59(1), pp. 65-70, 2009.

[7] Smit, J., Nasr, J. \& Ratta, A., Urban Agriculture: Food, Jobs and Sustainable Cities. UNDP: New York, 1996.

[8] Altieri, M.A., Hecht, S., Liebman, M., Magdoff, F., Norgaard, R. \& Sikor, T.O., Agroecología: Bases Científicas Para Una Agricultura Sustentable. Nordan-Comunidad, 1999.

[9] Lynch, K., Binns, T. \& Olofin, E., Urban agriculture under threat: The land security question in Kano, Nigeria. Cities, 18(3), pp. 159-171, 2001.

[10] Rodriguez, D.R. \& León, T.E., Agricultura urbana en Bogotá: adaptación cultural a los ecosistemas. En: Nail, S. Alimentar la ciudades. Ed. Universidad Externado de Colombia, pp.181-210, 2018. ISBN 978-958-772-927-6.

[11] Moran Alonso, N., Agricultura urbana: un aporte a la rehabilitación integral. Papeles de relaciones ecosociales y cambio global, 111 pp. 99-111, 2010 Online. http://oa.upm. es/12160/1/INVE_MEM_2010_76416.pdf (accessed on 23 May, 2018).

[12] Orangotango. Kollectiv für kritische bildung und kreativem protest. Online. http://orangotango.info/projekte/kollektives-kartieren/kritische-karten-2/ (accessed on 23 May, 2018). 